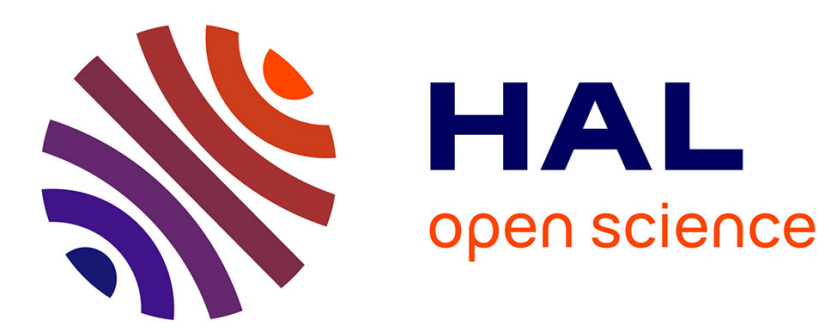

\title{
Preparation of Ultrafine CVD WC Powders Deposited from WCl6 Gas Mixtures
}

Xing Tang, R. Haubner, B. Lux, B. Kieffer

\section{To cite this version:}

Xing Tang, R. Haubner, B. Lux, B. Kieffer. Preparation of Ultrafine CVD WC Powders Deposited from WCl6 Gas Mixtures. Journal de Physique IV Proceedings, 1995, 05 (C5), pp.C5-1013-C5-1020. 10.1051/jphyscol:19955119 . jpa-00253789

\section{HAL Id: jpa-00253789 https://hal.science/jpa-00253789}

Submitted on 1 Jan 1995

HAL is a multi-disciplinary open access archive for the deposit and dissemination of scientific research documents, whether they are published or not. The documents may come from teaching and research institutions in France or abroad, or from public or private research centers.
L'archive ouverte pluridisciplinaire HAL, est destinée au dépôt et à la diffusion de documents scientifiques de niveau recherche, publiés ou non, émanant des établissements d'enseignement et de recherche français ou étrangers, des laboratoires publics ou privés. 


\title{
Preparation of Ultrafine CVD WC Powders Deposited from $\mathrm{WCl}_{6} \mathrm{Gas}$ Mixtures
}

\author{
X. Tang, R. Haubner, B. Lux and B. Kieffer* \\ Institute for Chemical Technology of Inorganic Materials, Technical University of Vienna, Getreidemarkt \\ 9/161, 1060 Vienna, Austria \\ * Teledyne Advanced Materials, Huntsville, Alabama, U.S.A.
}

\begin{abstract}
Ultrafine WC powders were produced from $\mathrm{WCl}_{6}-\mathrm{C}_{3} \mathrm{H}_{8}-\mathrm{H}_{2}$ gas mixtures in a conventional tubular hot-wall downstream CVD reactor. At reaction temperatures between 1100 and $1550^{\circ} \mathrm{C}$ powders containing $\mathrm{W}, \mathrm{W}_{2} \mathrm{C}, \mathrm{WC}$ and carbon were produced. The overall chemical compositions of the tungsten compounds as well as the free carbon contents depended strongly on the reaction temperature and the ratio of the reaction gases introduced.

With increased reaction temperature and exposure time the amount of tungsten carbides (WC, $\mathrm{W}_{2} \mathrm{C}$ ) in the deposits increased. At the selected conditions pure WC could be detected by $\mathrm{X}$-ray diffraction. However, excess carbon was always present, while carbon particles could not be observed by SEM in the powder mixtures. This could be explained by thin carbon layers on the carbide particles. The WC powder particles were very fine but only particles or agglomerates smaller than $0.5 \mu \mathrm{m}$ can be observed by SEM.

A deposition mechanism based on reduction of the chlorides and their carburization to the carbides is discussed.
\end{abstract}

\section{INTRODUCTION}

Of the various WC-based hard metals, the fine/ultrafine grained alloys have superior material properties which have attracted increasing interest [1-9]. The manufacture of this kind of cemented carbide requires fine/ultrafine WC powders as the main starting material. Thus the powder production becomes the first important step in the technical process. Decreasing the particle size of the WC by the traditional hydrogen reduction process of tungsten oxide has natural limits [10]. The CVD technique for the ultrafine powder production based on hydrogen reduction of tungsten halides has been studied by many authors [11-17]. A process described by Lamprey and Riply [11] uses hydrogen reduction of tungsten chlorides to produce W powders with average particle size of $0.01-0.1 \mu \mathrm{m}$. Zhao and Revankar [12-13] have studied the characteristics of hydrogen-chlorine flames. The effects of different parameters on the synthesis of $\mathrm{W}$ and WC powders by flame CVD gave encouraging results. Kim et al. [14-16] performed a series of experiments on the preparation of fine WC powders by vapor-phase reactions in tungsten-methane (and/or ethylene or propane)-hydrogen systems.

In the work reported here, attempts were made to establish a simpler and less expensive method for the production of ultrafine $\mathrm{WC}$ powders using $\mathrm{CVD}$ with $\mathrm{WCl}_{6}-\mathrm{C}_{3} \mathrm{H}_{8}-\mathrm{H}_{2}$ gas mixtures. 


\section{EXPERIMENTAL}

Commercially available tungsten chloride, $\mathrm{WCl}_{6}$ (b.p. $346.7^{\circ} \mathrm{C}$, m.p. $275^{\circ} \mathrm{C}$ ), was used as the tungsten source. The vapor pressure is summarized in Table 1 . Hydrogen $(99.999 \%)$ and propane $(99.95 \%)$ were used for reducing and carburizing the $\mathrm{WCl}_{6}$.

Table 1: Vapor pressure of $\mathrm{WCl}_{6}$

$180-230^{\circ} \mathrm{C}: \operatorname{lgP}=9.615-3996 / \mathrm{T}$

$230-281^{\circ} \mathrm{C}: \lg \mathrm{P}=8.794-3588 / \mathrm{T}$

$281-323^{\circ} \mathrm{C}: \operatorname{lgP}=8.194-3253 / \mathrm{T}$

\begin{tabular}{|c|c|}
\hline Temperature $\left({ }^{\circ} \mathrm{C}\right)$ & Pressure $(\mathrm{mmHg})$ \\
\hline 180 & 6.22 \\
200 & 14.68 \\
250 & 85.80 \\
300 & 328.70 \\
\hline
\end{tabular}

A downstream tube reactor was used for the experiments (Figure 1). The apparatus consisted of a sublimating and preheating tube for the $\mathrm{WCl}_{6}$, a tubular reactor of alumina heated by a tubular silicon carbide heating element, a powder collector and an exhaust gas adsorber.

Solid tungsten chloride was placed in a sublimating tube which was heated to the sublimation temperature $\left(150-200^{\circ} \mathrm{C}\right)$. A hydrogen/hydrocarbon mixture flowed over the solid $\mathrm{WCl}_{6}$, which partially evaporated. Since the saturation of the gas phase cannot be achieved, only the sublimation temperatures can give an indirect indication of the $\mathrm{WCl}_{6}$ concentrations. The reaction gases $\left(\mathrm{WCl}_{6}, \mathrm{H}_{2}\right.$, and $\mathrm{C}_{3} \mathrm{H}_{8}$ or $\mathrm{C}_{2} \mathrm{H}_{6}$ ) were mixed well and further heated in the preheating tube to $350^{\circ} \mathrm{C}$. The gas mixture then reached the downstream reactor where the powder formation took place between 1100 and $1500^{\circ} \mathrm{C}$. With respect to a deposition at $1500^{\circ} \mathrm{C}$ the reaction zone with temperature $1450 \pm 50^{\circ} \mathrm{C}$ was kept for $15 \mathrm{~cm}$. The powders were collected in a glass collector below the main reactor tube. Considering the pyrophoric properties of the fine powders obtained after the CVD experiments the system was flushed with nitrogen for 20 minutes before opening the reactor.

The components of the powders were identified by X-ray diffraction analysis and the morphologies and particle sizes by SEM. The total carbon contents of the powders were measured with a Carmhomat 6ADG carbon analyser.

A big problem with our small laboratory reactor was the cleaning of the reactor tube, which was necessary after each experiment in order to avoid the accumulation of reaction products, including carbon deposits, on the inner tube wall. These can influence subsequent experiments, leading even to a total obstruction of the tube. Since any mechanical treatment at high temperature could damage the alumina tube, an oxidation cleaning using flowing oxygen was tried. However the oxides formed are also difficult to remove from the tube.

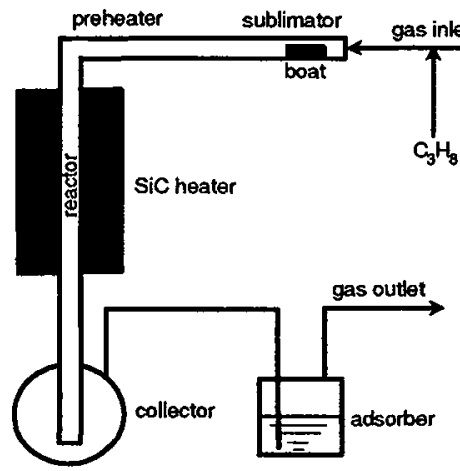

reactor tube diameter: $2.8 \mathrm{~cm}$ temperature gradient: $1450 \pm 50^{\circ} \mathrm{C}$ zone $15 \mathrm{~cm}$ resident time: about $4 \mathrm{sec}$

Figure 1: Schematic diagram of the downstream CVD reaction system 


\section{RESULTS}

The initial experiments were done with the systems $\mathrm{WCl}_{6}-\mathrm{C}_{3} \mathrm{H}_{8}-\mathrm{H}_{2}, \mathrm{WCl}_{6}-\mathrm{C}_{2} \mathrm{H}_{6}-\mathrm{H}_{2}$ and $\mathrm{WCl}_{6}-\mathrm{C}_{2} \mathrm{H}_{2}-\mathrm{H}_{2}$. In this paper only the results with propane $\left(\mathrm{C}_{3} \mathrm{H}_{8}\right)$ as carbon source are presented. Ethane $\left(\mathrm{C}_{2} \mathrm{H}_{6}\right)$ showed results similar to those for propane while acetylene $\left(\mathrm{C}_{2} \mathrm{H}_{2}\right)$ provided no satisfying results at all.

Within the $\mathrm{WCl}_{6}-\mathrm{C}_{3} \mathrm{H}_{8}-\mathrm{H}_{2}$ system several deposition parameters were varied and their influence on the quality of the powder deposited was examined.

In the powders containing pure WC an excess of free carbon was always present. The CVD powders so produced were treated in order to decrease free carbon content.

\subsection{The WC powder deposition}

An attempt was made to produce pure tungsten carbide through a CVD process using $\mathrm{WCl}_{6}-\mathrm{C}_{3} \mathrm{H}_{8}-\mathrm{H}_{2}$ gas mixtures. At normal gas pressure the influence of the reaction temperatures as well as the flow rates and concentrations of hydrogen and propane gases on the powder products obtained were studied.

\subsubsection{The deposition temperature}

X-ray-pure tungsten carbide (WC) could be produced at temperatures above $1400^{\circ} \mathrm{C}$ (Table 2). At lower temperatures, for example $1280^{\circ} \mathrm{C}$, the products contained large amounts of $\mathrm{WC}$ and $\mathrm{W}_{2} \mathrm{C}$ as well as small amounts of $W$. The experiments showed that the content of metallic tungsten in the powder increased with decreasing temperature. The composition of the products obtained depended strongly on the reaction temperature. Tungsten carbide appeared and its amount in the powder increased with increasing deposition temperatures until the WC became the only phase detected by X-ray. It is however always mixed with carbon.

Fig. 2 (a,b) shows the morphology and particle size as observed by SEM. It can be clearly seen that the particles are very fine $(0.2-0.5 \mu \mathrm{m})$, have a spherical morphology and are quite uniform in their size distribution. Agglomeration of the small particles is always observed (Fig. 2c,d).

Table 2: Operating conditions and results obtained with $\mathrm{WCl}_{6}-\mathrm{C}_{3} \mathrm{H}_{8}-\mathrm{H}_{2}$ gas mixtures $\left(300 \mathrm{ml} \mathrm{H} \mathrm{H}_{2} / \mathrm{min}\right)$.

\begin{tabular}{|c|c|c|c|}
\hline Temperature $\left({ }^{\circ} \mathrm{C}\right)$ & $\mathrm{C}_{3} \mathrm{H}_{8}(\mathrm{ml} / \mathrm{min})$ & X-ray diffraction analysis* & C content (wt\%) \\
\hline 1280 & 100 & $\mathrm{WC}(\mathrm{L}), \mathrm{W}_{2} \mathrm{C}(\mathrm{L}), \mathrm{W}(\mathrm{S})$ & 60.8 \\
\hline 1400 & 100 & $\mathrm{WC}(\mathrm{L}), \mathrm{W}_{2} \mathrm{C}(\mathrm{VS})$ & 89.7 \\
\hline 1400 & 50 & WC & 73.3 \\
\hline 1500 & 100 & WC & 90.4 \\
\hline 1500 & 50 & WC & 67.5 \\
\hline
\end{tabular}

* L-large amount, S-small amount, VS-very small amount
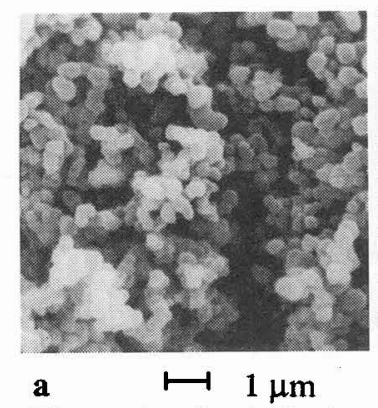

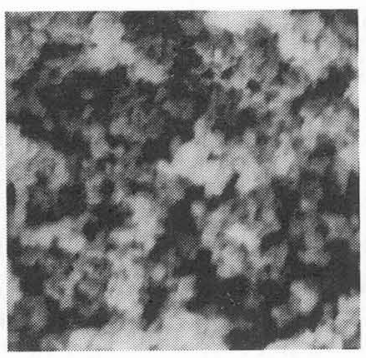

b $\longmapsto 1 \mu \mathrm{m}$

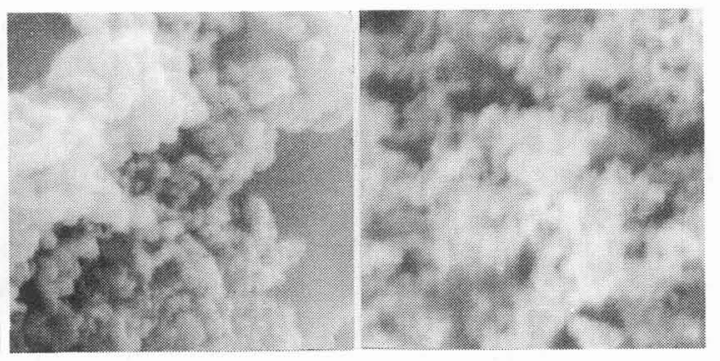

c $\longmapsto 1 \mu \mathrm{m}$ $1 \mu \mathrm{m}$

Figure 2: Morphologies and particle sizes observed for WC powders using SEM 


\subsubsection{The influence of the propane flow rate (carbon concentration)}

During the reactions excess hydrogen and propane were present compared to the $\mathrm{W}$ compounds. The relative amounts of the carbides $\mathrm{WC}$ and $\mathrm{W}_{2} \mathrm{C}$ as well as the amount of carbon black formed were influenced mainly by the decomposition temperature and the propane gas concentration (Table 3). Carbon analysis showed that the total carbon content in the powders was sometimes as much as ten times that of stoichiometric WC $(6.14 \% \mathrm{C})$. The effects of propane flow rates on this free carbon content are shown in Fig. 3 and 4.

At a reaction temperature of $1530^{\circ} \mathrm{C}\left(\mathrm{T}_{\text {subl }} 200^{\circ} \mathrm{C}, 250 \mathrm{ml} \mathrm{H} / \mathrm{min}\right)$ the carbon content increased linearly from 1.44 to $6.98 \mathrm{wt} \%$ with increased propane gas flow rates (from 16 to $24 \mathrm{ml} / \mathrm{min}$; Table 3, Fig.3). The $\mathrm{X}$-ray phase analysis showed that with low propane additions the powder consisted mainly of metallic tungsten. To reach the carbon content of stoichiometric WC $(6.14 \mathrm{wt} \%)$ a propane flow of about 23$23.5 \mathrm{ml} / \mathrm{min}$ should be used (see Figure 3). Under these deposition conditions increasing the propane gas flow rate proportionally increased the amounts of the additional free carbon deposited.

Table 3: Effects of propane flow on product composition and carbon content (reaction temp. $1530^{\circ} \mathrm{C}$; sublimation temp. $200^{\circ} \mathrm{C} ; \mathrm{H}_{2}: 250 \mathrm{ml} / \mathrm{min}$ )

\begin{tabular}{|c|c|c|}
\hline $\mathrm{C}_{3} \mathrm{H}_{8}(\mathrm{ml} / \mathrm{min})$ & $\mathrm{X}$-ray diffraction analysis* & C content (wt \%) \\
\hline 16 & $\mathrm{~W}(\mathrm{~L}), \mathrm{W}_{2} \mathrm{C}(\mathbf{S}), \mathrm{WC}(\mathbf{S})$ & 1.44 \\
\hline 17 & $\mathrm{~W}(\mathrm{~L}), \mathrm{W}_{2} \mathrm{C}(\mathrm{S}), \mathrm{WC}(\mathrm{S})$ & 1.39 \\
\hline 18 & $\mathrm{~W}(\mathrm{~L}), \mathrm{W}_{2} \mathrm{C}(\mathrm{C}), \mathrm{WC}(\mathrm{C})$ & 2.44 \\
\hline 20 & $\mathrm{WC}(\mathrm{L}), \mathrm{W}_{2} \mathrm{C}(\mathrm{S}), \mathrm{W}(\mathrm{S})$ & 3.80 \\
\hline 22 & $\mathrm{WC}(\mathrm{L}), \mathrm{W}_{2} \mathrm{C}(\mathrm{S}), \mathrm{W}(\mathrm{S})$ & 5.55 \\
\hline 24 & WC(VL), $\mathrm{W}_{2} \mathrm{C}(\mathbf{S}), \mathrm{W}(\mathbf{S})$ & 6.98 \\
\hline 50 & WC & 70.70 \\
\hline
\end{tabular}

* VL-very large amount, L-large amount, C-certain amount, S-small amount

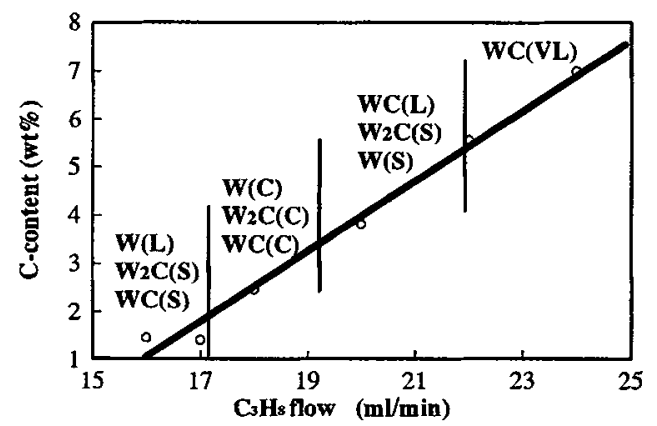

Figure 3: Effects of $\mathrm{C}_{3} \mathrm{H}_{8}$ flow on the $\mathrm{C}$ contents in powders produced in the $\mathrm{WCl}_{6}-\mathrm{C}_{3} \mathrm{H}_{8}-\mathrm{H}_{2}$ system (Reaction temp. $1530^{\circ} \mathrm{C} ; \mathrm{T}_{\text {subl. }} 200^{\circ} \mathrm{C}$; hydrogen flow rate $250 \mathrm{ml} / \mathrm{min}$ )

\subsubsection{Influence of the total flux (hydrogen flow rate)}

As shown in Table 3 and Figure 3 above, for a constant hydrogen flow a linear increase of the carbon content in the powders with the addition of propane was observed.

At a reaction temperature of $1500^{\circ} \mathrm{C}$, with a total $\left(\mathrm{H}_{2}\right)$ gas flow of 200 and $250 \mathrm{ml} / \mathrm{min}$, a $\mathrm{T}_{\text {subl }}$ of $175^{\circ} \mathrm{C}$ and a propane flow being varied between 17 and $25 \mathrm{ml} / \mathrm{min}$ the results shown in Table 4 and Figure 4 were obtained. These data reveal that the change in the hydrogen flow rate has less influence on the carbon content in the powder (Figure 4) than the propane gas flow rate has. 
Table 4: Effects of $\mathrm{C}_{3} \mathrm{H}_{8}$ flow on $\mathrm{C}$ contents in powders produced in the $\mathrm{WCl}_{6}-\mathrm{C}_{3} \mathrm{H}_{8}-\mathrm{H}_{2}$ system (sublimation. temp. $175^{\circ} \mathrm{C}$; reaction temp. $1500^{\circ} \mathrm{C}$ )

\begin{tabular}{|c|l|c|}
\hline \multicolumn{3}{|c|}{$200 \mathrm{ml} \mathrm{\mathbf {H } _ { 2 } / \text { min }}$} \\
\hline $\begin{array}{c}\mathrm{C}_{3} \mathrm{H}_{8} \\
(\mathrm{ml} / \mathrm{min})\end{array}$ & X-ray diffraction analysis* & $\begin{array}{c}\text { C content } \\
(\mathrm{wt} \%)\end{array}$ \\
\hline 17 & $\mathrm{~W}(\mathrm{~L}), \mathrm{W}_{2} \mathrm{C}(\mathrm{S}), \mathrm{WC}(\mathrm{S})$ & 2.56 \\
20 & $\mathrm{WC}(\mathrm{L}), \mathrm{W}_{2} \mathrm{C}(\mathrm{S}), \mathrm{W}(\mathrm{S})$ & 5.90 \\
23 & $\mathrm{WC}(\mathrm{L}), \mathrm{W}_{2} \mathrm{C}(\mathrm{S}), \mathrm{W}(\mathrm{S})$ & 9.15 \\
24 & $\mathrm{WC}(\mathrm{VL}), \mathrm{W}_{2} \mathrm{C}(\mathrm{S}), \mathrm{W}(\mathrm{VS})$ & 10.21 \\
\hline
\end{tabular}

\begin{tabular}{|c|l|c|}
\hline \multicolumn{3}{|c|}{$250 \mathrm{ml} \mathrm{H} / \mathrm{min}$} \\
\hline $\begin{array}{c}\mathrm{C}_{3} \mathrm{H}_{8} \\
(\mathrm{ml} / \mathrm{min})\end{array}$ & X-ray diffraction analysis* & $\begin{array}{c}\text { C content } \\
\text { (wt\%) }\end{array}$ \\
\hline 18 & $\mathrm{~W}(\mathrm{~L}), \mathrm{W}_{2} \mathrm{C}(\mathrm{S}), \mathrm{WC}(\mathrm{S})$ & 2.98 \\
19 & $\mathrm{WC}(\mathrm{L}), \mathrm{W}_{2} \mathrm{C}(\mathrm{C}), \mathrm{W}(\mathrm{C})$ & 4.22 \\
20 & $\mathrm{WC}(\mathrm{L}), \mathrm{W}_{2} \mathrm{C}(\mathrm{S}), \mathrm{W}(\mathrm{S})$ & 5.43 \\
21.5 & $\mathrm{WC}(\mathrm{L}), \mathrm{W}_{2} \mathrm{C}(\mathrm{S}), \mathrm{W}(\mathrm{S})$ & 7.13 \\
\hline
\end{tabular}

* VL-very large amount, L-large amount, C-certain amount, S-small amount, VS-very small amount

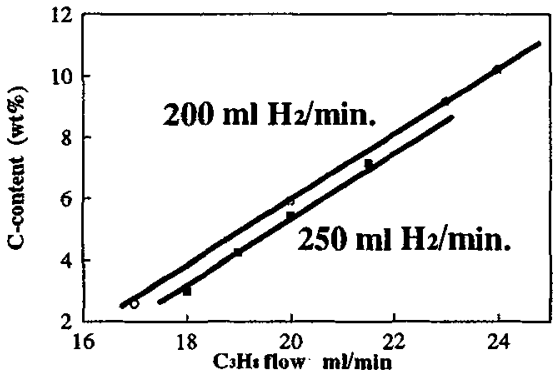

Figure 4: Effects of $\mathrm{C}_{3} \mathrm{H}_{8}$ flow on $\mathrm{C}$ contents in powders produced in the $\mathrm{WCl}_{6}-\mathrm{C}_{3} \mathrm{H}_{8}-\mathrm{H}_{2}$ system (Reaction temp. $1500^{\circ} \mathrm{C} ; \mathrm{T}_{\text {subl. }} 175^{\circ} \mathrm{C}$ )

\subsection{Removal of the carbon black from the CVD - WC powder mixtures}

Carbon black deposited on the WC particles can be converted into hydrocarbons at $800-1000^{\circ} \mathrm{C}$ in flowing hydrogen. The powders obtained by CVD containing tungsten carbides, tungsten and large amounts of carbon black were placed in a ceramic boat and put into a tube furnace. Conversion of carbon black into hydrocarbons (e.g. methane) takes place at $1000^{\circ} \mathrm{C}$ so that a significant reduction of the free carbon content was possible (Table 5). Treatment times between 20 and 60 minutes allowed the substantial reduction of the carbon black to a usable carbon content.

For the above described experiments powders containing large amounts of WC, certain amounts of W and small amounts of $\mathrm{W}_{2} \mathrm{C}$ with a total carbon content of $15.4 \mathrm{wt} \%$ were treated at $1000^{\circ} \mathrm{C}\left(1501 \mathrm{H}_{2} / \mathrm{h}\right)$. The experiments indicated that the carbon black can be easily removed from the powder mixture obtained by the CVD reaction. After 10 minutes of treatment the $\mathrm{C}$ content was reduced from $15.4 \%$ to $11.1 \%$. After $60 \mathrm{~min}$, the carbon content was decreased to 5.4\%. However, no further change in carbon content occurred even after longer treatment times. $\mathrm{X}$-ray diffraction showed that at this $\mathrm{C}$ content the powders consisted of very large amounts of $\mathrm{WC}$ with very small amounts of $\mathrm{W}_{2} \mathrm{C}$ and $\mathrm{W}$.

Table 5: Removal of carbon black by conversion into $\mathrm{CH}_{4}\left(1000^{\circ} \mathrm{C}, \mathrm{H}_{2}\right.$ flow rate $\left.150 \mathrm{~V} / \mathrm{h}\right)$

\begin{tabular}{|c|l|c|}
\hline Time (min.) & X-ray diffraction analysis* & C content (wt\%) \\
\hline 0 & WC(L), W(C), $\mathrm{W}_{2} \mathrm{C}(\mathrm{S})$ & 15.4 \\
10 & WC(VL), $\mathrm{W}_{2} \mathrm{C}(\mathrm{S})$ & 11.1 \\
20 & WC(VL), $\mathrm{W}_{2} \mathrm{C}(\mathrm{S})$ & 10.4 \\
60 & WC(VL), $\mathrm{W}_{2} \mathrm{C}(\mathrm{VS}), \mathrm{W}(\mathrm{VS})$ & 5.4 \\
100 & WC(VL), $\mathrm{W}_{2} \mathrm{C}(\mathrm{VS}), \mathrm{W}(\mathrm{VS})$ & 5.4 \\
\hline
\end{tabular}

* VL-very large amount, L large amount, C-certain amount, S-small amount, VS-very small amount 


\section{DISCUSSION}

Many chemical reactions are involved in the CVD formation of WC powder. Since both kinetic and thermodynamic equilibrium conditions must be taken in consideration the total process is quite complex.

\subsection{The WC powder deposition}

The following reactions ((1) to (6)) can occur in the $\mathrm{WCl}_{6}-\mathrm{C}_{3} \mathrm{H}_{8}-\mathrm{H}_{2}$ system during powder deposition:
$\mathrm{WCl}_{6}+3 \mathrm{H}_{2} \rightarrow \mathrm{W}+6 \mathrm{HCl}$
$\mathrm{W}+\mathrm{C} \rightarrow \mathrm{W}_{2} \mathrm{C}$
$\begin{aligned} \mathrm{C}_{3} \mathrm{H}_{8} & \rightarrow 3 \mathrm{C}+4 \mathrm{H}_{2} \\ \mathrm{~W}_{2} \mathrm{C}+\mathrm{C} & \rightarrow 2 \mathrm{WC}\end{aligned}$

The overall reaction can be described as:

$$
3 \mathrm{WCl}_{6}+5 \mathrm{H}_{2}+\mathrm{C}_{3} \mathrm{H}_{8} \rightarrow 3 \mathrm{WC}+18 \mathrm{HCl}
$$

The reaction for carbon dissolution is:

$$
\mathrm{C}+2 \mathrm{H}_{2} \rightarrow \mathrm{CH}_{4}
$$

Partial reduction of $\mathrm{WCl}_{6}$ to low valence tungsten chloride and partial dissociation of propane are involved during the deposition. Reaction (1) takes place above $400^{\circ} \mathrm{C}$ [11]. The cracking of propane (Reaction (2)) and carburization of tungsten (reactions (3) and (4)) occurs at much higher temperatures. Preliminary experiments carried out at $900^{\circ} \mathrm{C}$ showed that only $\mathrm{W}$ was formed, and neither $\mathrm{W}_{2} \mathrm{C}$ nor WC were detected, which proved the necessity of high temperature. The higher the temperature, the faster are the reaction rates for the WC formation.

The following model can be used to understand the formation of WC particles and free carbon:

- First metallic W particles are formed by reaction (1).

- $\mathrm{C}_{3} \mathrm{H}_{8}$ present in the gas phase is then adsorbed on the $\mathrm{W}$ particles and starts their carburization. At higher temperatures the propane can be cracked, and other carbon compounds can also be involved in the carburization process.

- Thin WC layers are formed on the surfaces of the W particles; since the diffusion coefficient of C in WC is so low, these layers act as barriers for the further diffusion of carbon into the $\mathrm{W}$ particles, making further carburization.

- During the carburization $\mathrm{W}_{2} \mathrm{C}$ is formed as intermediate layer between metallic $\mathrm{W}$ and the WC.

- If there is excess $\mathrm{C}$ in the gas phase, for example from the pyrolysis of propane, carbon can be deposited on the $\mathrm{W} / \mathrm{W}_{2} \mathrm{C} / \mathrm{WC}$ particles, covering them with a thin layer.

- This carbon layer can be dissolved by hydrogen at higher temperatures (reaction (6)). The SEM never did show any carbon black particles between the carbides. Thus the assumption of external carbon shells around the WC particles is reasonable and can be assumed. Due to the enormous surface areas of the submicron particles the layers do not need to be very thick to explain the large amounts of excess carbon always found deposited together with the carbide particles.

- The carburization of single tungsten particle should behave like the reaction of conventional process in which carbon gradually diffuses from outside to inside, remaining tungsten in the center if an incomplete carburization is achieved.

Figure 5 illustrates the steps described above. Based on this general model all the parameters influencing the powder formation and the powder composition can be explained.
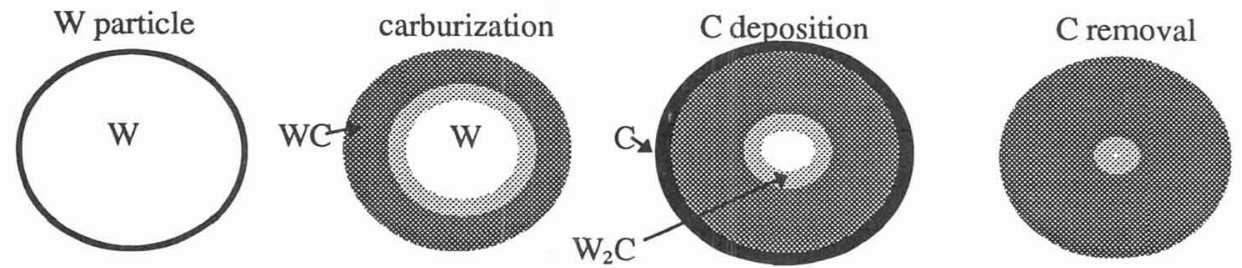

Figure 5: Descriptive model of the WC powder formation 


\subsection{The deposition parameters}

- The reaction temperature influences the reaction rates of the $\mathrm{W}$ particle formation and of the carbon formation by the propane decomposition. The main mode is the increasing carbon diffusion in the WC layers with increasing temperatures. Even the relatively large particles can be fully carburized at the higher reaction temperatures.

- The propane concentration directly influences the carbon content in the powders. Under certain selected conditions even the stoichiometric content of $6.14 \% \mathrm{C}$ could be reached, although there was still metallic tungsten in the particles. This shows that not only the $\mathrm{C}$ content can be used to characterize the quality of the powder. In general, for constant deposition conditions increasing propane concentration results in higher carbon black contents in the CVD powders. The propane concentration necessary for stoichiometric WC powders also depends on the $\mathrm{WCl}_{6}$ concentration (Table 6 ).

- Both the hydrogen gas flow rate and the $\mathrm{WCl}_{6}$ sublimation temperature influence the concentrations of the reactants in the gas phase, which in turn help determine the particle size as well as the final composition of the powder.

- Temperature gradient at the inlet of the reactor influences the reduction, of the $\mathrm{WCl}_{6}$ and the powder size. A longer heating zone is certainly advantageous for a complete carburization. A resident time of the powders, longer than that necessary for carburization, results in higher $\mathrm{C}$ content because of further cracking of propane.

Table 6: Amount of propane required for preparation of stoichiometric WC at different sublimation temperatures

\begin{tabular}{|c|c|c|c|}
\hline $\begin{array}{c}\text { Reaction } \\
\text { temp. }\left({ }^{\circ} \mathrm{C}\right)\end{array}$ & $\begin{array}{c}\mathrm{H}_{2} \\
(\mathrm{ml} / \mathrm{min})\end{array}$ & $\begin{array}{c}\text { Sublimation } \\
\text { temp. }\left({ }^{\circ} \mathrm{C}\right)\end{array}$ & $\begin{array}{c}\mathrm{C}_{3} \mathrm{H}_{8} \\
(\mathrm{ml} / \mathrm{min})\end{array}$ \\
\hline 1530 & 250 & 150 & $15-16$ \\
1530 & 250 & 175 & $20-20.5$ \\
1530 & 250 & 200 & $23-23.5$ \\
\hline
\end{tabular}

More work is needed however to optimize the reaction parameters so that stoichiometric, X-ray-pure WC can be reliably produced.

\subsection{Control of carbon content and particle size of powder products}

$\mathrm{X}$-ray-pure WC with a stoichiometric $\mathrm{C}$ content could be more readily produced if the particle size was small and the temperature high. In this case the particles could be fully carburized during the short time of deposition.

If the particle size exceeded $0.5 \mu \mathrm{m}$ and the deposition temperature decreased, the powder composition becomes less homogeneous. Because of the short deposition time (about $4 \mathrm{sec}$ ) the larger particles could not be fully carburized, since $C$ diffusion was slower at the lower temperatures. Thus particles with WC and $\mathrm{W}_{2} \mathrm{C}$ shells surrounding $\mathrm{W}$ cores can be expected to form. In order to reach the stoichiometric WC eomposition, the free carbon shell arround the particle is needed so that stoichiometric WC can be formed during the heat treatment. In the work reported here it was possible to produce "near-stoichiometric" WC powders containing between 5.90 and $6.98 \mathrm{wt} \% \mathrm{C}$.

The agglomeration influences the properties of final product - hard metal. Comparing with the conventional powders, the agglomeration of the CVD powder is much lower. The agglomerates can be broken easily during the subsequent deagglomeration. It must be kept in mind that a certain degree of agglomeration will always remain, due to the inherent chemical and physical forces acting between the individual particles (10). 


\subsection{Reduction of the carbon content by hydrogen treatment}

Since the free carbon is deposited as a shell around the WC particles, chemical reactions can be used to remove this excess carbon. A high-temperature method with hydrogen was used to solve this problem. During this treatment two goals can be reached simultaneously:

- $W$ and $\mathrm{W}_{2} \mathrm{C}$ in the particle cores can be carburized during the heat treatments. Highly mobile hydrocarbons (mainly $\mathrm{CH}_{4}$ ) can transport carbon to other powder particles with lower carbon contents.

- Carbon layers deposited on the WC particles can be removed, leading to a stoichiometric C content. For the industrial production of high-quality powders the conditions of this last step must be optimized. If the carbon removal is too rapid the $\mathrm{W}$ and $\mathrm{W}_{2} \mathrm{C}$ cannot be transformed into $\mathrm{WC}$ and the resulting powder will remain sub-stoichiometric.

\section{CONCLUSION}

X-ray-pure WC particles could be produced by a high-temperature CVD process. The powders were not pyrophoric in air.

The powders can contain significant amounts of excess carbon black. Controlling the hydrocarbon concentration in the $\mathrm{WCl}_{6}-\mathrm{C}_{3} \mathrm{H}_{8}-\mathrm{H}_{2}$ system led to powder mixtures with total carbon contents ranging from 5.5-6.9 wt\%. X-ray diffraction indicated that the powders consisted of large amounts of WC, with small amounts of $\mathrm{W}_{2} \mathrm{C}$ and $\mathrm{W}$.

The best experimental conditions for the preparation of near-stoichiometric WC were found to be: reaction temperature: $1500^{\circ} \mathrm{C}$ hydrogen flow: $\quad 250 \mathrm{ml} / \mathrm{min}$

propane flow $\quad 15-16 \mathrm{ml} / \mathrm{min}$ (for sublimation temperature $150^{\circ} \mathrm{C}$ ) $20-20.5 \mathrm{ml} / \mathrm{min}$ (for sublimation temperature $175^{\circ} \mathrm{C}$ ) $23-23.5 \mathrm{ml} / \mathrm{min}$ (for sublimation temperature $200^{\circ} \mathrm{C}$ )

The removal of carbon black from the powder by its chemical conversion was readily possible under flowing hydrogen at temperatures below $1000^{\circ} \mathrm{C}$. With the proper amount of excess carbon the $\mathrm{W}$ and $\mathrm{W}_{2} \mathrm{C}$ originally present in the powder could be converted into $\mathrm{WC}$.

\section{References}

[1] Lardner E. and Iggstrom S., Proc. $10^{\text {th }}$ Int. Plansee Seminar, Reutte, Austria, 1 (1981) 549-579

[2] Bock A., Schubert W.D. and Lux B., Powder Metallurgy, 24(1) (1992) 20-26

[3] Fukatsu T., Kobori K. and Ueki M., Int.J. Ref. Met. and Hard Meter., 10(2) (1991) 57-60

[4] Tönshoff H.K. and Spiting W., Proc. $13^{\text {th }}$ Int. Plansee Seminar, Reutte, Austria, 3 (1993) 656-666

[5] Imasato S., Tokumoto K., Kitaba T. and Sakagucki S., Proc. $13^{\text {th }}$ Int. Plansee Seminar, Reutte, Austria, 3 (1993) 688-700

[6] Lindskog P., Powder Metallurgy International, 25(3) (1993) 138-142

[7] Schubert W.D. and Lassner E., Int. J. Ref. Met. and Hard Meter., 10(3) (1991) 133

[8] Schubert W.D. and Lassner E., Int. J. Ref. Met. and Hard Meter., 10(4) (1991) 171

[9] Fang Z. and Eason J.M., Proc. $13^{\text {th }}$ Int. Plansee Seminar, Reutte, Austria, 3 (1993) 625-638

[10] Schubert W.D., Bock A., Lux B., Proc. $13^{\text {th }}$ Int. Plansee Seminar, Reutte, Austria, 4 (1993) 283

[11] Lamprey H. and Ripley R.L., J. of Electrochemical Society, 109(8) (1962) 713-715

[12] Zhao G.Y. and Revanker V., J. Less-commen Metals, 163 (1990) 269

[13] Revanker V. and Zhao G.Y., Ind. Eng. Chem. Res., 30 (1991) 2344

[14] Kim Soo Sik and Kim Han San, Taehan Kumsok Hakhoechi, 29(6) (1991) 640

[15] Kim Soo Sik and Kim Han San, Taehan Kumsok Hakhoechi, 29(7) (1991) 651

[16] Kim Soo Sik and Kim Han San, Taehan Kumsok Hakhoechi, 29(7) (1991) 659

[17] Hojo J., Otu T. and Katu A., J. Less-Commen Metals, 59 (1978) 85 